\title{
PENGARUH PEMBERIAN INSENTIF TERHADAP KINERJA PEGAWAI PADA DINAS PENDIDIKAN KABUPATEN SUBANG
}

\author{
Oleh : \\ Luki Natika \\ Fakultas Ilmu Administrasi Universitas Subang \\ luckynatika@gmail.com
}

\begin{abstract}
ABSTRAK
Penelitian yang penulis lakukan pada Kantor Dinas Pendidikan dan Kebudayaan Kabupaten Subang bertujuan untuk mengetahui pengaruh pemberian insentif terhadap kinerja pegawai pada Dinas Pendidikan dan Kebudayaan Kabupaten Subang. Adapun lokasi yang dijadikan tempat penelitian adalah Kantor Dinas Pendidikan dan Kebudayaan Kabupaten Subang yang beralamat di Jalan Dewi Sartika No 2 Subang Telp. (0260) 411005.

Dalam penelitian ini penulis menggunakan metode penelitian dengan menggunakan metode Asosiatif karena metode penelitian asosiatif merupakan penelitian yang bertujuan untuk mengetahui hubungan antara dua variabel atau lebih, sedangkan teknik pengumpulan data yang digunakan adalah studi kepustakaan dan studi lapangan melalui observasi, wawancara dan penyebaran kuesioner. Metode pengambilan data dengan metode Sensus yaitu pengambilan sampel secara keseluruhan dari populasi yang telah ditentukan.

Dalam analisis data penulis menggunakan dua jenis kajian, pertama menggunakan analisis deskriptif untuk menjelaskan fenomena pada setiap variabel, Kedua menggunakan Analisis inferensial untuk pengambilan keputusan berdasarkan analisis data dengan melakukan pengujian hipotesis.

Hasil penelitian menunjukan bahwa terdapat pengaruh yang Sangat Kuat antara variabel pemberian insentif dengan Kinerja Pegawai pada Dinas Pendidikan dan Kebudayaan Kabupaten Subang ini terlihat dari hasil yang diperoleh dari hasil Correlations kedua variabel tersebut sebesar 0.810

Bertitik tolak dari hasil penelitian diatas maka hipotesis yang diajukan adalah "Terdapat pengaruh pemberian insentif terhadap kinerja pegawai Dinas Pendidikan dan Kebudayaan Kabupaten Subang" dapat diterima.
\end{abstract}




\section{ABSTRACT}

Research conducted by the author at the Education and Culture Office of Subang Regency aims to determine the effect of incentives on the performance of employees at the Department of Education and Culture District Subang. As for the location to be a place of research is the Office of Education and Culture Subang Regency is located at Jalan Dewi Sartika No. 2 Subang Tel. (0260) 411005.

In this study the author uses research methods using associative method because the method of associative research is research that aims to determine the relationship between two or more variables, while the data collection techniques used are literature studies and field studies through observation, interviews and questionnaires. The method of collecting data by census method that is the overall sampling of the population who have been determined.

In the data analysis the authors used two types of studies, first using descriptive analysis to explain the phenomenon in each variable, two using inferential analysis for decision-making based on analysis of data to test hypotheses.

The results showed that there are significant Powerful between variable incentives with Employee Performance at the Department of Education and Culture of Subang Regency is evident from the results obtained from the results of these two variables Correlations of 0810.

Based on the above results, the hypothesis is "There is the influence of incentives on the performance of staff at the Department of Education and Culture of Subang Regency" unacceptable.

\section{PENDAHULUAN}

Manajemen sumber daya manusia merupakan satu bidang manajemen yang khusus mempelajari hubungan dan peranan manusia dalam organisasi. Manajemen sumber daya manusia mengatur tenaga kerja yang ada di dalam organisasi, sehingga terwujud tujuan organisasi kepuasan kerja pegawai. Manajemen sumber daya manusia juga dapat menghasilkan kinerja yang baik dalam sebuah perusahaan dengan cara penilaian, pemberian balas jasa dalam setiap individu anggota organisasi sesuai dengan kemampuan kerjanya.Sumber daya manusia dipandang sebagai aset penting organisasi, karena manusia merupakan sumber daya yang dinamis dan selalu dibutuhkan dalam setiap proses penyelesaian pekerjaan. Sumber daya manusia merupakan faktor yang sentral dalam keberlangsungan suatu organisasi. Apapun bentuk serta tujuannya, organisasi dibuat berdasarkan visi untuk kepentingan manusia dan dalam pelaksanaan misinya dikelola dan diatur oleh manusia, sehingga sesempurna apapun sebuah organisasi tanpa adanya campur tangan manusia, kegiatan pencapaian tujuan tidak akan berjalan. Seseorang yang bekerja akan merasa lebih dihargai oleh masyarakat di sekitarnya, dibandingkan yang tidak bekerja. Untuk menjamin tercapainya keselarasan tujuan, pimpinan organisasi bisa memberikan perhatian dengan memberikan kompensasi, karena kompensasi merupakan bagian dari hubungan timbal balik antara organisasi dengan sumber daya manusia. Dalam organisasi untuk dapat dapat melaksanakan tugas sesuai dengan perannya di pemerintahan, para pegawai harus mempunyai keunggulan kompetitif yang sangat sulit ditiru, yang hanya akan diperoleh dari pegawai yang produktif, inovatif, kreatif selalu bersemangat dan loyal. Pegawai yang memenuhi kriteria seperti itu hanya akan dimiliki melalui penerapan konsep dan teknik manajemen sumber daya manusia yang tepat dengan semangat kerja yang tinggi. Untuk meningkatkan kinerja seorang pegawai di organisasi dengan cara pemberian imbalan yang sebanding dengan pekerjaan yang telah pegawai lakukan. Apabila seseorang yang telah bekerja melampaui target membuat pegawai mendapatkan imbalan dari hasil kinerja yang telah dicapai.

Di dalam organisasi adalah kompensasi yang memadai. Kompensasi adalah segala sesuatu yang diterima para pegawai sebagai balas jasa untuk kerja mereka. Kompensasi juga merupakan penghargaan yang diberikan pegawai baik langsung maupun tidak langsung, finansial maupun non finansial yang adil kepada pegawai atas kinerja mereka dalam mencapai tujuan organisasi, sehingga pemberian kompensasi sangat dibutuhkan oleh organisasi manapun guna meningkatkan kinerja pegawainya. Adapun bentuk kompensasi 
finansial adalah gaji, tunjangan, bonus (insentif), dan komisi. Sedangkan untuk kompensasi non-finansial diantaranya pelatihan, wewenang dan tanggung jawab, penghargaan atas kinerja serta lingkungan kerja yang mendukung. Jadi untuk mendapatkan kompensasi yang sesuai dengan kinerja pegawai maka dibutuhkan pula pegawai yang memiliki potensi yang baik guna tercapainya tujuan bersama. Oleh karena itu di dalam sebuah kompensasi terdapat beberapa kompensasi berupa kompensasi finansial yaitu insentif. Insentif merupakan pemberian uang di luar gaji yang dilakukan oleh pemimpin organisasi sebagai pengakuan terhadap kinerja pegawai kepada organisasi. Apabila insentif yang diberikan organisasi sudah tepat, maka insentif yang diberikan akan meningkatkan kinerja pegawai. Kinerja merupakan hasil dan prilaku kerja yang dihasilkan oleh seorang pegawai sesuai dengan perannya dalam organisasi pada suatu periode tertentu. Kinerja pegawai yang baik adalah salah satu faktor yang sangat penting dalam upaya untuk meningkatan kinerja pegawai dan produktivitas. Oleh karena itu salah satu cara terbaik untuk meningkatkan kinerja pegawai adalah dengan memberikan insentif kepada pegawai agar dapat memotivasi sehingga pegawai lebih meningkatkan lagi kinerjanya, sehingga kinerjanya meningkat dan organisasipun mampu menghasilkan prestasi kerja yang tinggi.

Pemberian insentif merupakan salah satu hal pokok yang harus diperhatikan oleh organisasi. Semangat tidaknya pegawai bisa juga disebabkan oleh besar kecilnya insentif yang diterima. Apabila pegawai tidak mendapatkan insentif yang sesuai dengan besarnya pengorbanan dalam bekerja, maka pegawai tersebut cenderung malas bekerja dan tidak bersemangat yang ada akhirnya mereka bekerja semaunya tanpa ada kepuasan kerja yang memadai, yaitu sebagaimana diharapkan oleh pegawai tersebut. Pegawai merupakan unsur penting dalam organisasi yang harus memiliki motivasi dan kemampuan kerja yang tinggi, karena motivasi akan mempengaruhi terhadap kinerja pegawai. Oleh karena itu pegawai harus dikembangkan dengan cara, antara lain melalui pemberian insentif yang berkesinambungan, berdampak pada peningkatan kinerja maupun prestasi kerja. Fungsi pemberian insentif kepada pegawai selain untuk menumbuhkan kinerja pegawai, juga untuk untuk mendapat nilai tambah dari penghasilan yang diperolehnya. Insentif merupakan wujud perhatian pimpinan organisasi terhadap pekerjaan yang telah dilakukan dengan penuh semangat dan tanggung jawab. Pemberian insentif bukan hanya dari bentuk materi, tetapi bisa juga diberikan dalam bentuk pujian dan penghargaan atas prestasi yang telah dicapainya. Dengan demikian insentif merupakan sarana motivasi kepada para pegawai dalam meningkatkan kinerjanya yang pada dasarnya akan berpengaruh terhadap pencapaian tujuan organisasi secara keseluruhan.

Pemberian insentif juga memegang peranan penting dalam meningkatkan kinerja pegawai, karena salah satu alasan utama seorang bekerja adalah untuk memenuhi kebutuhan hidupnya dari imbalan yang mereka terima dari bekerja. Dalam sebuah organisasi, pemberian insentif merupakan perangsang bagi pegawai. Hal ini sangat perlu karena mempunyai pengaruh terhadap pegawai agar lebih giat lagi bekerja dalam menyelesaikan tugas-tugas yang telah diberikan, sehingga pekerjaan dapat diselesaikan sesuai dengan rencana yang telah ditetapkan. Kinerja pegawai dihasilkan dari fungsi pegawai tertentu atau kegiatan yang dilakukan selama periode waktu tertentu. Sedangkan kinerja suatu jabatan secara keseluruhan sama dengan jumlah (ratarata) dari kinerja fungsi pegawai atau kegiatan yang dilakukan (Handoko (2002:78). Tujuan utama dari pemberian insentif ini sebenarnya untuk merangsang atau memberikan dorongan kepada pegawai supaya mau melaksanakan pekerjaannya melebihi standart yang telah ada atau melebihi kemampuan rata-rata, juga untuk memotivasi pegawai agar pegawai tersebut dapat meningkatkan prestasi kerjanya

Pengukuran kinerja merupakan suatu proses mencatat dan mengukur pencapaian pelaksanaan kegiatan dalam arah pencapaian sasaran, tujuan, misi dan visi melalui hasil-hasil yang ditampilkan beberapa produk, jasa ataupun proses pelaksanaan suatu kegiatan. Keberhasilan instansi pemerintah sering diukur dari sudut pandang masing-masing stakeholders, misalnya lembaga legislatif, instansi pemerintah, dan masyarakat umum. Idealnya pengukuran kinerja yang dipakai oleh 
instansi pemerintah disusun setelah memperoleh masukan dari lembaga legislatif, sehingga diperoleh suatu konsensus atas apa yang diharapkan oleh stakeholders terhadap organisasi tersebut.

Kinerja merupakan hasil dan prilaku kerja yang dihasilkan oleh seorang pegawai sesuai dengan perannya dalam organisasi dalam suatu periode tertentu. Oleh karena, itu salah satu cara terbaik untuk meningkatkan kinerja pegawai adalah dengan memberikan insentif kepada pegawai agar dapat memotivasi sehingga pegawai lebih meningkatkan lagi kinerjanya, sehingga kinerjanya meningkat dan organisasi pun mampu menghasilkan prestasi kerja yang tinggi. Dinas Pendidikan merupakan unsur pendukung tugas Pemerintah Daerah di bidang pendidikan dipimpin oleh seorang Kepala Dinas yang berada di bawah dan bertanggung jawab kepada Bupati melalui Sekretaris Daerah. Dinas Pendidikan mempunyai tugas pokok melaksanakan kewenangan Daerah di bidang pendidikan serta tugas pembantuan yang diberikan oleh Pemerintah atau Pemerintah Provinsi Jawa Barat Berdasarkan hasil penelitian yang penulis

\section{METODE}

Dalam studi penelitian, penggunaan metodologi merupakan suatu langkah yang harus ditempuh, agar hasil-hasil yang sudah terseleksi dapat terjawab secara valid, reliabel dan obyektif, dengan tujuan dapat ditemukan, dibuktikan dan dikembangkan suatu pengetahuan, sehingga dapat digunakan untuk mamahami, memecahkan, dan mengantisipasi masalah dalam bidang administrasi publik. Penelitian deskriptif adalah penelitian yang dilakukan untuk mengetahui nilai variabel mandiri, baik satu variabel atau lebih (independen) tanpa membuat perbandingan, atau menghubungkan antara variabel satu dengan variabel yang lain (Sugiyono, 2010 : 11). Selain itu Metode penelitian yang digunakan dalam penelitian ini adalah dengan menggunakan metode asosiatif karena metode penelitian asosiatif merupakan penelitian yang bertujuan untuk mengetahui hubungan antara dua variabel atau lebih. Sugiyono (2010 : 11). Tujuan metode Asosiatif ini adalah untuk membangun suatu teori yang dapat berfungsi untuk menjelaskan, meramalkan, dan mengontrol suatu gejala. Adalah wilayah lakukan pada Kantor Dinas Pendidikan Kabupaten Subang terdapat masalah yaitu kinerja pegawai belum optimal, hal ini dilihat dari indikator-indikator sebagai berikut:

1. Target penyelesaian rekapitulasi dokumen laporan bulanan adalah satu hari, ternyata realisasinya 3 hari, jadi baru bisa diselesaikan tepat waktu baru 50\%

2. Kehadiran pegawai pada jam bekerja di kantor hanya sebanyak 65\%, banyak pegawai yang meninggalkan kantor sebelum waktu jam istirahat disebabkan kurang antusias dalam melaksanakan tugas

3. Keandalan pegawai dalam melaksanakan pekerjaan masih rendah, rendahnya inisiatif pegawai, dikarenakan para pegawai hanya menunggu perintah dari atasan sehingga bekerja ketika ada atasannya.

4. Kurang terjalinnya komunikasi yang baik antara pimpinan bawahan, sehingga setiap ada pekerjaan pimpinan harus memberi tahu bawahan tentang pekerjaan yang harus diselesaikan

generalisasi yang terdiri atas obyek atau subyek yang mempunyai kuantitas dan karakteristik tertentu yang di tetapkan oleh peneliti untuk dipelajari dan diambil kesimpulannya (Sugiyono, 2010 : 90). Dengan demikian yang menjadi populasi dalam penelitian ini adalah Pegawai Dinas Pendidikan Kabupaten Subang

\section{HASIL DAN PEMBAHASAN}

Sebelum dilakukan pengujian hipotesis, dilakukan terlebih dahulu pengujian terhadap instrumen penelitian (angket) yang digunakan, dengan maksud untuk mengetahui validasi, (ketepatan pertanyaan), reliabilitas (ketetapan penyusunan pertanyaan).

Adapun seluruh responden dalam penelitian ini sebanyak 54 orang dan yang menjadi subyek dalam penelitian ini yaitu pegawai Pegawai Dinas Pendidikan dan Kebudayaan Kabupaten Subang.

\section{Uji Kualitas Data}

Sebelum alat ukur berupa lembar kuesioner tesebut digunakan terlebih dahulu diuji coba, tujuan uji coba ini adalah untuk mengetahui apakah instrument ini bisa 
digunakan atau tidak. Instrument yang telah disiapkan benar-benar dapat digunakan sebagai alat ukur yang tepat, sesuai atau diharapkan (validitas) dan untuk mengetahui tingkat kehandalan hasil pengukuran yang dilakukan (reliablitas)

\section{Uji Validitas}

Kuesioner yang disebarkan kepada responden dilakukan uji validitas dan reliabilitas instrumen dengan cara mengkorelasikan skor butir dengan menggunakan rumus korelasi product moment. Sesuai dengan pendapat Masrun dalam
Sugiono (2010 : 152) bahwa "item yang mempunyai korelasi positif dengan kriterium (skor total) serta korelasi yang tinggi, menunjukkan bahwa item tersebut mempunyai syarat adalah kalau $r=0,30$ ". Jadi suatu butir dikatakan valid apabila didapatkan angka korelasi lebih besar dengan r-kritis sebesar 0,30 . Kondisi sebaliknya kalau $r$ kurang dari 0,30 maka butir dalam instrumen penelitian tersebut dinyatakan tidak valid.

Berdasarkan hasil pengujian data untuk variabel pemberian insentif didapatkan hasil sebagai berikut :

Hasil Pengujian Validitas Instrumen Pemberian Insentif

\begin{tabular}{llll} 
Pernyataan & r Hitung & r Kritis & Keterangan \\
\hline X_01 & 0.463 & 0,30 & Valid \\
\hline X_02 & 0.467 & 0,30 & Valid \\
\hline X_03 & 0.340 & 0,30 & Valid \\
\hline X_04 & 0.491 & 0,30 & Valid \\
\hline X_05 & 0.341 & 0,30 & Valid \\
\hline X_06 & 0.537 & 0,30 & Valid \\
\hline X_07 & 0.618 & 0,30 & Valid \\
\hline X_08 & 0.378 & 0,30 & Valid \\
\hline X_09 & 0.400 & 0,30 & Valid \\
\hline X_10 & 0.536 & 0,30 & Valid \\
\hline X_11 & 0.445 & 0,30 & Valid \\
\hline X_12 & 0.404 & 0,30 & Valid \\
\hline X_13 & 0.468 & 0,30 & Valid \\
\hline$X \_14$ & 0.503 & 0,30 & Valid \\
\hline$X \_15$ & 0.492 & 0,30 & Valid \\
\hline
\end{tabular}

Sumber : Kuisioner (Data Diolah Kembali)

Seperti telah dikemukakan bahwa bila koefisien korelasi sama dengan 0.3 atau lebih (paling kecil 0,3), maka butir instrumen dinyatakan valid. Dari hasil pengujian diatas, ternyata koefisien korelasi semua butir dengan skor total di atas 0,3 , sehingga semua butir instrumen pengawasan dinyatakan valid. Butir yang mempunyai validitas tertinggi adalah butir X_07 dengan koefisien korelasi 0,618 dan yang paling rendah adalah butir X_03, dengan koefisien korelasi 0,340.

Sedangkan untuk validitas Kinerja Pegawai hasil pengujian validitas didapatkan hasil sebagai berikut : 
Hasil Pengujian Validitas Instrumen Kinerja Pegawai

\begin{tabular}{llll} 
Pernyataan & r Hitung & r Kritis & Keterangan \\
\hline Y_01 & 0.492 & 0.30 & Valid \\
\hline Y_02 & 0.473 & 0.30 & Valid \\
\hline Y_03 & 0.559 & 0.30 & Valid \\
\hline Y_04 & 0.604 & 0.30 & Valid \\
\hline Y_05 & 0.323 & 0.30 & Valid \\
\hline Y_06 & 0.414 & 0.30 & Valid \\
\hline Y_07 & 0.634 & 0.30 & Valid \\
\hline Y_08 & 0.620 & 0.30 & Valid \\
\hline Y_09 & 0.584 & 0.30 & Valid \\
\hline Y_10 & 0.414 & 0.30 & Valid \\
\hline Y_11 & 0.336 & 0.30 & Valid \\
\hline Y_12 & 0.381 & 0.30 & Valid \\
\hline
\end{tabular}

Sumber : Kuisioner (Data Diolah Kembali)

Dari tabel 4.5 di atas ke enam butir pertanyaan pada variabel Kinerja Pegawai dinyatakan valid, dimana yang tertinggi adalah adalah butir Y_07 dengan koefisien korelasi 0,634 dan terendah butir Y_05 dengan koefisien korelasi 0,323 . Pengujian tersebut mengindikasikan bahwa instrumen kinerja pegawai secara tegas semuanya valid dan seluruh pertanyaan tersebut dapat diikut sertakan dalam menganalisis data.

\section{Uji Reliabilitas}

Untuk pengujian Reliabilitas, Penulis menggunakan metode konsistensi antar butir yakni dengan rumus Cronbach's Alpha. Jika koefisien Alpha Cronbach telah ditemukan, kemudian dibandingkan kriteria dimana reliabilitas kurang dari 0,6 menunjukkan instrumen dianggap "kurang baik", apabila disekitar angka 0,7 dikatagorikan "dapat diterima" dan untuk nilai diatas 0,8 digolongkan reliabilitas yang "baik".

Berikut ini penulis sajikan hasil pengujian reliabilitas instrumen pemberian insentif, antara lain sebagai berikut :

Reliability Statistics
\begin{tabular}{|l|l|}
\hline $\begin{array}{l}\text { Cronbach's } \\
\text { Alpha }\end{array}$ & N of Items \\
\hline 837 & 15 \\
\hline
\end{tabular}

Hasil uji reliabilitas berdasarkan hasil pengujian untuk variabel pemberian insentif didapatkan nilai alpha $(\alpha)$ sebesar 0,837 maka uji reliabilitas dinyatakan reliable.
Untuk hasil pengujian reliabilitas instrumen Kinerja Pegawai, antara lain sebagai berikut :

Reliability Statistics

\begin{tabular}{|l|l|}
\hline $\begin{array}{l}\text { Cronbach's } \\
\text { Alpha }\end{array}$ & N of Items \\
\hline .821 & 12 \\
\hline
\end{tabular}


Hasil uji reliabilitas berdasarkan hasil pengujian untuk variabel Kinerja didapatkan nilai alpha $(\alpha)$ sebesar 0,821 maka uji reliabilitas dinyatakan reliable.

\section{Deskripsi Pemberian Insentif}

Pemberian insentif adalah dorongan pada seseorang agar mau bekerja dengan baik dan agar lebih dapat mencapai tingkat kinerja yang lebih tinggi sehingga dapat membangkitkan gairah kerja dan motivasi seorang pegawai, jadi seseorang mau bekerja dengan baik apabila dalam dirinya terdapat motivasi, yang menjadi masalah adalah bagaimana pula menciptakan gairah kerja dan motivasinya, sebab walaupun motivasi sudah terbentuk apabila tidak disertai dengan gairah kerjanya maka tetap saja pegawai tersebut tidak akan bisa bekerja sesuai yang diharapkan.
Berkaitan dengan hal tersebut, pada bab ini akan membahas mengenai pelaksanaan pemberian insentif pada Dinas Pendidikan dan Kebudayaan Kabupaten Subang. Menurut Manulang (2006 : 4), pada dasarnya bentuk insentif dapat digolongkan menjadi dua bagian yaitu Insentif Finansial dan Insentif Non Finansial sebagai berikut :

Selanjutnya untuk mendeskripsikan secara jelas tentang variansi jawaban responden atas pernyataan yang diajukan, makat data mentah yang diperoleh tersebut disusun ke dalam databel yang dibedakan menurut dimensi masing-masing.

\section{Insentif Finansial}

Untuk mengetahui pernyataan dari responden tentang Indikator Insentif Finansial, berikut ini penulis sajikan pada tabel berikut ini

\begin{tabular}{|c|c|c|c|c|c|c|c|c|c|}
\hline \multirow{3}{*}{ No } & \multicolumn{8}{|c|}{ Pendapat Responden Tentang Insentif Finansial } & \multirow{3}{*}{$\begin{array}{l}\text { Indek } \\
\text { Rata-Rata }\end{array}$} \\
\hline & \multirow{2}{*}{ Indikator } & \multicolumn{5}{|c|}{ Pilihan Responden } & \multirow{2}{*}{ Jumlah } & \multirow{2}{*}{ Indeks } & \\
\hline & & 1 & 2 & 3 & 4 & 5 & & & \\
\hline 1 & Pembayaran pokok & 0 & 5 & 20 & 27 & 2 & 54 & 188 & 3.5 \\
\hline 2 & Pembayaran prestasi & 0 & 4 & 19 & 31 & 0 & 54 & 189 & 3.5 \\
\hline 3 & $\begin{array}{l}\text { Pembayaran } \\
\text { tertangguh }\end{array}$ & 0 & 0 & 16 & 36 & 2 & 54 & 202 & 3.7 \\
\hline 4 & Perlindungan pegawai & 0 & 4 & 20 & 28 & 2 & 54 & 190 & 3.5 \\
\hline 5 & $\begin{array}{l}\text { Pembayaran di luar } \\
\text { jam kerja }\end{array}$ & 0 & 1 & 10 & 39 & 4 & 54 & 208 & 3.9 \\
\hline 6 & Fasilitas Kerja & 0 & 4 & 14 & 34 & 2 & 54 & 196 & 3.6 \\
\hline \multicolumn{9}{|c|}{ Jumlah } & 21.7 \\
\hline \multicolumn{9}{|c|}{ Rata-rata } & 3.6 \\
\hline
\end{tabular}

Sumber : Data Primer yang diolah, 2017

Berdasarkan tabel di atas bahwa hasil jawaban responden tentang insentif finansial yang mencapai nilai rata-rata 3.6 dan masuk kriteria "Baik". Artinya sebagian besar responden menilai bahwa pemberian tunjangan berupa gaji dan upah sudah memenuhi harapan para pegawai Dinas Pendidikan dan Kebudayaan Kabupaten Subang. Namun demikian, jumlah responden yang merasa belum sepenuhnya terpenuhi kebutuhannya melalui indikator ini juga cukup banyak. Bahkan yang sama sekali menolak pemenuhan melalui tunjangan berupa gaji dan upah juga jumlahnya juga cukup dominan. Dengan kata lain bisa dikatakan bahwa persepsi pegawai Dinas Pendidikan dan Kebudayaan Kabupaten Subang Kabupaten Subang mengenai indikator

ini relatif beragam, walau tidak merata distribusinya.

Untuk bonus dan penyisihan dari keuntungan organisasi. Persepsi pegawai Dinas Pendidikan dan Kebudayaan Kabupaten Subang Kabupaten Subang atas indikator ini ternyata lebih terkonsentrasi pada sikap yang meragukan peran indikator ini, walau tidak sedikit pula yang sudah merasakan dampak ekonomi keluarga dan adanya pembayaran prestasi ini. Hampir separuh responden meragukan atau setidaknya belum merasakan indikator bonus serta penyisihan dari pendapatan yang diperoleh dari Dinas Pendidikan dan Kebudayaan Kabupaten Subang Kabupaten Subang dalam memenuhi kebutuhan sehari-hari. 
Mengenai pembayaran tertangguh yang bentuknya berupa tabungan dan bentuk lain yang serupa, ternyata baru dinikmati oleh separuh dari responden. Hal ini dimungkinkan karena sifat dari tabungan ini tidak mengikat dan formatnya sukarela. Partisipasi pegawai Dinas Pendidikan dan Kebudayaan Kabupaten Subang dalam aktivitas menabung dari pendapatannya per bulan juga lebih dimungkinkan terbuka bagi pegawai berstatus PNS dengan pangkat tertentu yang tingkat penghasilannya relatif lebih tinggi. Walau demikian cukup banyak juga pegawai yang meragukan dampak tabungan terhadap peningkatan pendapatan sebagai salah sata bentuk insentif atas pekajaannya. Dengan kata lain, mereka menilai bahwa tabungan belum sepenuhnya menjadi bentuk insentif sebagaimana yang selama ini diterapkan pada organisasi swasta.

Untuk perlindungan pegawai sebagian besar pegawai pada Dinas Pendidikan dan Kebudayaan Kabupaten Subang belum merasa memperoleh perlindungan kerja. Ada sebagian dari mereka secara berjenjang meragukan, merasa tidak dilindungi, bahkan sampai pendapat paling negatif tentang adanya perlindungan kerja ini. Dominannya tanggapan masih lemahnya perlindungan ini sangat dimungkinkan berhubung tidak sedikit pula pegawai yang statusnya non-PNS, sehingga jaminan perlindungan atas kelanjutan karienya tidak sepenuhnya terjamin.

Mengenai pembayaran di luar jam kerja yang umumnya diistilahkan dengan pembayaran uang lembur, pendapat responden secara umum terbagi dua kelompok besar. Kelompok pertama menilai bahwa pembayaran uang lembur sudah memenuhui harapan yang diinginkan, sernentara kelompok kedua meragukan dan sebagian kecil lagi menolak adanya dampak keberadaan uang lembur pada pemenuhan kebutuhan keuangan keluarga. Sebagaimana diketahui dalam penganggaran di lingkungan Pemenntah Kabupaten Subang, pembayaran uang di luar jam kerja atau uang lembur hanya diberlakukan bagi pegawai yang sudah berstatus PNS. Sedangkan bagi PNS yang pangkat/golongannya masih rendah dan masa kerjanya belum lama, besarnya honornya juga relatif kecil.

Untuk fasilitas kerja responden berpendapat bahwa hampir setengah dari responden menilai bahwa fasilitas kerja yang menunjang bagi Dinas Pendidikan dan Kebudayaan Kabupaten Subang Kabupaten Subang belum memenuhi tuntutan kebutuhan secara ideal. Hal mi dinilai pula oleh sebagian kecil lagi dari responden yang menilai bahwa fasilitas kerja ini sama sekali belum mampu mendukung dalam pelaksanaan kerja pegawai Dinas Pendidikan dan Kebudayaan Kabupaten Subang. Keterbatasan sarana pendukung ini merupakan dampak dari keterbatasan anggaran yang sudah menjadi masalah umum setiap unit kerja pemerintah. Namun patut pula mendapat perhatian dan pengambil kebijakan, bahwa indikator ini akan menjadi variabel yang menentukan keberhasilan proses pelaksanaan kerja pegawai pada Dinas Pendidikan dan Kebudayaan Kabupaten Subang yang sudah mulai membutuhkan perlengkapan yang didukung teknologi

\section{Insentif Non Finansial}

Untuk mengetahui pernyataan dari responden tentang Indikator Non Insentif Finansial, berikut ini penulis sajikan pada tabel berikut ini :

Pendapat Responden Tentang Insentif Non Finansial

\begin{tabular}{|c|c|c|c|c|c|c|c|c|c|}
\hline \multirow{2}{*}{ No } & \multirow{2}{*}{ Indikator } & \multicolumn{5}{|c|}{ Pilihan Responden } & \multirow{2}{*}{ Jumlah } & \multirow{2}{*}{ Indeks } & \multirow{2}{*}{$\begin{array}{l}\text { Indek Rata- } \\
\text { Rata }\end{array}$} \\
\hline & & 1 & 2 & 3 & 4 & 5 & & & \\
\hline 1 & Tugas yang menarik & 0 & 9 & 16 & 25 & 4 & 54 & 186 & 3.4 \\
\hline 2 & $\begin{array}{l}\text { Tantangan } \\
\text { pekerjaan }\end{array}$ & 0 & 1 & 15 & 36 & 2 & 54 & 201 & 3.7 \\
\hline 3 & Tanggung Jawab & 0 & 2 & 15 & 33 & 4 & 54 & 201 & 3.7 \\
\hline 4 & Pengakuan & 0 & 9 & 15 & 28 & 2 & 54 & 185 & 3.4 \\
\hline 5 & Rasa Pencapaian & 0 & 0 & 17 & 36 & 1 & 54 & 200 & 3.7 \\
\hline 6 & Kebijakan yang sehat & 0 & 1 & 14 & 35 & 4 & 54 & 204 & 3.8 \\
\hline 7 & Supervisi yg kompeten & 0 & 5 & 17 & 30 & 2 & 54 & 191 & 3.5 \\
\hline
\end{tabular}




$\begin{array}{lllllllllll}8 & \begin{array}{l}\text { Kerabat Kerja } \\ \text { menyenangkan }\end{array} & \text { yang } & 0 & 3 & 19 & 32 & 0 & 54 & 191 & 3.5 \\ 9 \quad \begin{array}{l}\text { Lingkungan kerja } \\ \text { nyaman }\end{array} & 0 & 6 & 16 & 32 & 0 & 54 & 188 & 3.5 \\ \text { Jumlah } & & & & & & & & & & 32.4 \\ \text { Rata-rata } & \end{array}$

Berdasarkan tabel di atas bahwa hasil jawaban responden tentang insentif non finansial yang mencapai nilai rata-rata 3.6 dan masuk kriteria "Baik". Artinya sebagian besar responden menilai bahwa penghargaan atau insentif non finansial sudah dirasakan cukup baik. Hal ini tentu harus mendapat perhatian dan pimpinan Dinas Pendidikan dan Kebudayaan, dimana aspek tugas yang menarik dapat menjadi aspek yang tinggi pengaruhnya terhadap kinerja organisasi. Bahkan di sisi lain, aspek tugas yang menarik ini dapat menjadi faktor substitusi untuk menutupi kelemahan di sektor lain dalam aspek insentif, misalnya gaji yang rendah atau fasilitas yang minim. Sedangkan aspek tantangan dalam pekerjaan diperoleh informasi, para pegawai para Dinas Pendidikan dan Kebudayaan Kabupaten Subang sebagian besar sudah menilai bahwa pekerjaan yang rutin dilaksanakan ini sudah menjadi tantangan tersendiri dalam meningkatkan profesionalisme kerjanya. Sebagian kecil ada yang berpendapat bahwa untuk meningkatkan profesionalisme pagawai ini perlu mendapat perhatian khusus dari pimpinan, karena tuntutan kebutuhan peningkatan kinerja pegawai dalam suatu organisasi dari tahun ke tahun harus mengalami peningkatan dalam kinerjanya.

Aspek tanggung jawab dari pekerjaan yang dilaksanakan di Dinas Pendidikan dan Kebudayaan juga belum sepenuhnya memenuhi harapan pegawai. Dari jawaban responden di atas, tampak masih ada responden meragukan pentinpya aspek tanggung jawab pekerjaan ini, bahkan terdapat juga pegawai yang menolak pentingnya aspek ini. Namun di sisi lain mayoritas pegawai yang menilai bahwa pekerjaan yang dilaksanakan memang harus disertai dengan tanggung jawab sebagai pegawai pelayan publik, Aspek tanggung jawab atas pekerjaan ini bagaimanapun harus menjadi perhatian khusus bagi semua pegawai Dinas Pendidikan dan Kebudayaan, karena menyangkut masalah akuntabilitas maupun responsibilitas yang sangat menuntukan tinggi rendahnya kinerja organisasi pelayanan publik.

Aspek pengakuan, tampak bahwa sebagian besar responden belum memperoleh pengakuan atas hasil kerja yang merupakan output dari Dinas Pendidikan dan Kebudayaan. Tingginya pendapat tersebut dikarenakan masih rendahnya penilaian pimpinan atas hasil kerja dalam pelaksanaan pekerjaan dalam pelayanan publik. Konteks pengakuan atas hasil kerja im akan sangat berpengaruh pada kepuasan pegawai atas output yang dihasilkannya dan akan menjadi motivasi tersendiri bagi peningkatan profesionalisme pegawai. Dari hasil tabel di atas, dapat disimpulkan bahwa sebagian pegawai yang memang sudah memperoleh pengakuan atas hasil kerjanya, dan ini sudah patut dijadikan sebagai modal pengembangan bagi pegawai yang belum memperoleh pengakuan atas hasil kerja.

Aspek Rasa Pencapaian terkait dengan kepuasan pegawai atas hasil kerja yang dihasilkan dalam melaksanakan pekerjaan, dalam konteks ini, pegawai menilai dirinya sendiri tentang sejauh mana hasil kerja yang menjadi output kerjanya. Dari tabel di atas, ternyata belum semua pegawai merasa bahwa rasa pencapaian yang diperoleh atas pekerjaannya belum sepenuhnya tercapai. Ada sebagian pegawai meragukan diperolehnya rasa pencapaian, bahkan terdapat pula pegawai yang sama sekali belum memperoleh rasa pencapaian, namun sebagian besar pegawai yang sudah memperoleh rasa pencapaian atas hasil pekerjaan. Asepk kebijakan yang sehat dalam melaksanakan tugas pekerjaan pada Dinas Pendidikan dan Kebudayaan secara umum dapat dikatakan terbelah pada polarisasi antara yang menerima dan menolak atas kebijakan yang ditempuh. Dari tabel di atas, tampak bahwa terdapat sebagian pegawai yang menilai bahwa kebijakan yang ditempuh oleh Dinas Pendidikan dan Kebudayaan belum sesuai dengan potensi yang dimiliki pegawai. Walau demikian, persepsi ini diimbangi oleh sebagian besar pegawai yang menilai bahwa kebijakan yang ditempuh Dinas Pendidikan dan Kebudayaan pada saat peneilitian dilakukan, 
sudah sesuai dengan visi den misi yang sudah ditetapkan sebelumnya.

Aspek supervisi dalam penelitian ini berkaitan dengan kemampuan atasan/ pimpinan dalam melakukan pengawasan atas pelaksanaan pekerjaan yang dilakukan pegawai. Dari tabel di atas, terlihat bahwa sebagian besar pegawai Dinas Pendidikan dan Kebudayaan sudah menilai baik aspek pengawasan yang dilakukan oleh atasan/ pimpinan dalam pelaksanaan pekerjaan. Dalam konteks ini, sebagian besar pegawai menilai bahwa atasan/pimpinan sudah mampu melaksanakan pengawasan yang berdasarkan prinsip-prinsip sebagai salah satu fungsi manajemen. Aspek pengawasan yang ditempuh di Dinas Pendidikan dan Kebudayaan tampaknya masih terbatas pada hal-hal tertentu saja. Hal ini terlihat dari adanya persepsi responden yang menilai bahwa pengawasan memang sudah diterapkan dalam pelaksanaan tugas sehari-hari.

Aspek Supervisi yang kompeten, terhitung banyak pegawai yang menilai bahwa rekan kerja dalam pelaksanaan tugas dipandang sebagai rekan kerja yang menyenangkan. Sebagian besar responden menilai bahwa rekan kerja sehari-hari dirasakan menyenangkan dan mendukung pelaksanaan pekerjaan. Lebih dari itu, walaupun persentasenya kecil, terdapat pula sebagian pegawai yang menilai bahwa rekan kerja yang menyenangkan belum dirasakan dan berdampak langsung pada penyelesaian pekerjaan. Aspek Lingkungan kerja yang nyaman, sebagian responden menilai bahwa lingkungan kerja di Dinas Pendidikan dan Kebudayaan sudah dinilai baik. Hal ini terlihat dan pendapat responden yang menyetujui adanya lingkungan kerja yang menyenangkan malaupun persentase tidak terlalu signifikan. Hal ini sudah dapat dijadikan menjadi potensi baik untuk dapat diterapkan pada sebagian pegawai yang belum menilai baik lingkungan kerja yang mereka rasakan sehari-hari. Hal ini perlu mendapat perhatian tersendiri berhubung pegawai yang merasa ragu-ragu dan sama sekali tidak merasakan atas keberadaan lingkungan kerja yang menyenangkan ternyata cukup tinggi. Apabila tidak perhatikan dikhawatirkan aspek ini akan berdampak negatif dan meluas pada pegawai-pegawai yang selama ini sudah merasakan suasana kerja yang menyenangkan.

\section{Rekapitulasi Skor Variabel Pemberian Insentif}

Untuk mengetahui hasil rekapitulasi pernyataan dari responden tentang Variabel Pemberian Insentif, berikut ini penulis sajikan tabel berikut ini :

\begin{tabular}{|c|c|c|c|c|c|c|c|c|c|}
\hline \multirow{3}{*}{ No } & \multicolumn{9}{|c|}{ Pendapat Responden Tentang Variabel Kinerja } \\
\hline & \multirow{2}{*}{ Indikator } & \multicolumn{5}{|c|}{ Pilihan Responden } & \multirow{2}{*}{ Jumlah } & \multirow{2}{*}{ Indeks } & \multirow{2}{*}{$\begin{array}{l}\text { Indek } \\
\text { Rata-Rata }\end{array}$} \\
\hline & & 1 & 2 & 3 & 4 & 5 & & & \\
\hline 1 & Pembayaran pokok & 0 & 5 & 20 & 27 & 2 & 54 & 188 & 3.5 \\
\hline 2 & Pembayaran prestasi & 0 & 4 & 19 & 31 & 0 & 54 & 189 & 3.5 \\
\hline 3 & $\begin{array}{l}\text { Pembayaran } \\
\text { tertangguh }\end{array}$ & 0 & 0 & 16 & 36 & 2 & 54 & 202 & 3.7 \\
\hline 4 & Perlindungan pegawai & 0 & 4 & 20 & 28 & 2 & 54 & 190 & 3.5 \\
\hline 5 & $\begin{array}{l}\text { Pembayaran di luar } \\
\text { jam kerja }\end{array}$ & 0 & 1 & 10 & 39 & 4 & 54 & 208 & 3.9 \\
\hline 6 & Fasilitas Kerja & 0 & 4 & 14 & 34 & 2 & 54 & 196 & 3.6 \\
\hline 7 & Tugas yang menarik & 0 & 9 & 16 & 25 & 4 & 54 & 186 & 3.4 \\
\hline 8 & $\begin{array}{l}\text { Tantangan dalam } \\
\text { pekerjaan }\end{array}$ & 0 & 1 & 15 & 36 & 2 & 54 & 201 & 3.7 \\
\hline 9 & Tanggung Jawab & 0 & 2 & 15 & 33 & 4 & 54 & 201 & 3.7 \\
\hline 10 & Pengakuan & 0 & 9 & 15 & 28 & 2 & 54 & 185 & 3.4 \\
\hline 11 & Rasa Pencapaian & 0 & 0 & 17 & 36 & 1 & 54 & 200 & 3.7 \\
\hline 12 & Kebijakan yang sehat & 0 & 1 & 14 & 35 & 4 & 54 & 204 & 3.8 \\
\hline 13 & Supervisi yg kompeten & 0 & 5 & 17 & 30 & 2 & 54 & 191 & 3.5 \\
\hline
\end{tabular}




$\begin{array}{llllllllll}14 & \begin{array}{l}\text { Kerabat Kerja yang } \\ \text { menyenangkan }\end{array} & 0 & 3 & 19 & 32 & 0 & 54 & 191 & 3.5 \\ 15 \quad \begin{array}{l}\text { Lingkungan kerja yang } \\ \text { nyaman }\end{array} & 0 & 6 & 16 & 32 & 0 & 54 & 188 & 3.5 \\ \text { Jumlah } & & & & & & & & 54.1 \\ \text { Rata-rata } & & & & & & & & 3.6\end{array}$

Sumber : Data Primer yang diolah, 2017

Dari tabel di atas, ternyata sebagian besar responden telah memperoleh insentif secara memadai. Sekalipun demikian, terdapat juga sebagian pegawai yang belum memperoleh insentif secara memadai dengan persentase cukup signifikan. Dominannya persentase pegawai yang sudah merasakan dampak dari insentif dimungkinkan oleh tanggapan responden yang sudah berstatus PNS, terlebih lagi bagi mereka yang sudah memperoleh tunjangan karena jabatannya, baik struktural maupun fungsional.

\section{Deskripsi Kinerja Pegawai}

Kinerja merupakan catatan outcome yang dihasilkan dari fungsi pegawai tertentu atau kegiatan yang dilakukan selama periode waktu tertentu. Sedang kinerja suatu jabatan secara keseluruhan sama dengan jumlah (ratarata) dari kinerja fungsi pegawai atau kegiatan yang dilakukan. Pengertian kinerja di sini tidak bermaksud menilai karakteristik individu tetapi

mengacu pada serangkaian hasil yang diperoleh selama periode waktu tertentu

Indikator atau ukuran kinerja menurut Michael (dalam Sedarmayanti, 2006 : 59) yang terdiri sebagai berikut:

1. Kualitas Hasil Kerja

2. Ketepatan Waktu

3. Inisiatif

4. Kemampuan

5. Komunikasi

Untuk memperkuat kajian permasalahan tersebut maka berikut ini penulis akan menguraikan pembahasan terhadap masing-masing indikator kinerja pegawai tersebut yang diperoleh dari hasil wawancara, pengamatan serta diperkuat oleh angket yang disebarkan kepada responden.

\section{Kualitas Hasil Kerja}

Untuk mengetahui pernyataan dari responden tentang indikator kualitas hasil kerja, berikut ini penulis sajikan tabel berikut ini :

Pendapat Responden Tentang Kualitas Kerja

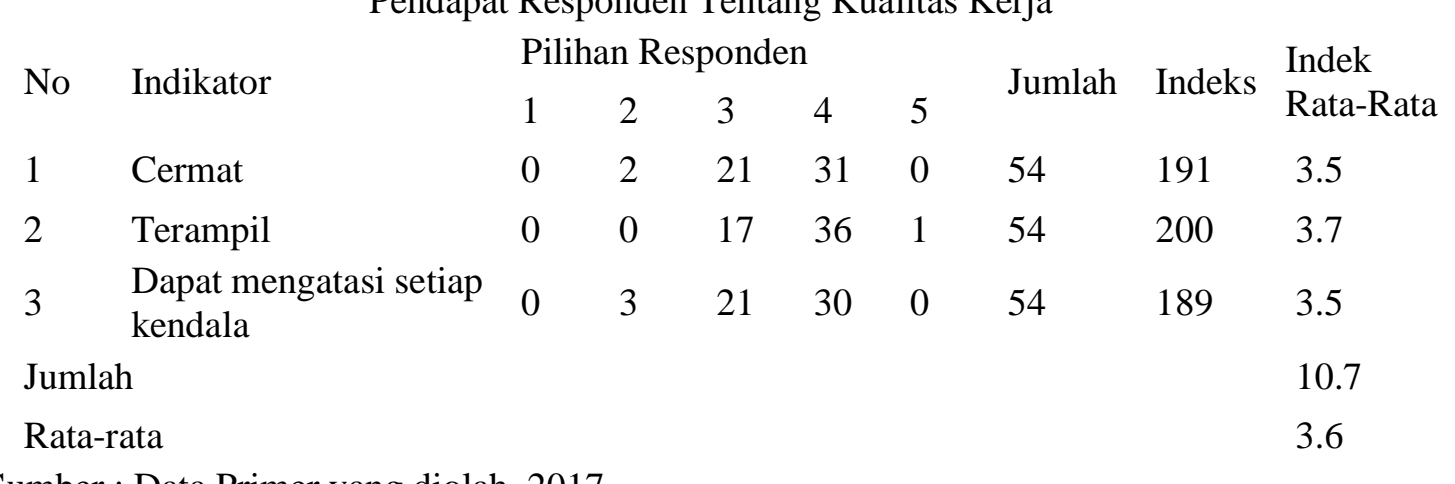

Sumber : Data Primer yang diolah, 2017

Berdasarkan tabel di atas, sebagian besar responden menilai bahwa pegawai pada Dinas Pendidikan dan Kebudayaan Kabupaten Subang dalam melaksanakan tugas pekerjaan sesuai dengan prosedur pekerjaan yang telah ditentukan dinilai oleh responden sudah baik. Hal ini terlihat dan pendapat responden yang mayoritas menyetujui bahwa para pegawai dalam melaksanakan tugas pekerjaan sesuai dengan prosedur pekerjaan yang telah ditentukan. Hal ini sudah dapat dijadikan menjadi potensi baik untuk dapat diterapkan pada pegawai yang dinilai belum melaksanakan tugas pekerjaan sesuai dengan prosedur pekerjaan yang telah ditentukan.

Sebagaimana pada indikator menekankan kualitas pekerjaan kepada pegawai, tanggapan responden atas menekankan kualitas pekerjaan kepada pegawai dari pegawai pegawai Dinas 
Pendidikan dan Kebudayaan Kabupaten Subang sudah menunjukan adanya peningkatan kualitas hasil pekerjaan. Hal ini terlihat dari dominannya persentase jawaban responden yang memberikan pendapat setuju atas menekankan kualitas pekerjaan kepada pegawai.

Hal ini perlu mendapat dukungan lebih maksimal dari pimpinan, sehingga pegawai yang menilai ragu bahwa pegawai Dinas Pendidikan dan Kebudayaan Kabupaten Subang dalam melaksanakan tugas pekerjaan sesuai dengan prosedur pekerjaan yang telah ditentukan sudah maksimal. Apabila tidak meningkat dukungan dikhawatirkan akan berdampak negatif dan meluas pada pegawai yang selama ini telah menilai baik terhadap hasil pelaksanaan kerja pegawai.

\section{Ketepatan Waktu}

Untuk mengetahui pernyataan dari responden tentang Indikator menghindari penyimpangan dari aturan yang berlaku, berikut ini penulis sajikan tabel berikut ini :

Pendapat Responden Tentang Ketepatan Waktu

\begin{tabular}{llllllllll} 
No & Indikator & \multicolumn{1}{c}{ Pilihan Responden } & & Jumlah & Indeks & Indek \\
Rata-Rata
\end{tabular}

Sumber : Data Primer yang diolah, 2017

Dalam menghindari penyimpangan dari aturan yang berlaku para pegawai Dinas Pendidikan dan Kebudayaan Kabupaten Subang, baik yang berkaitan dengan pelanggaran disiplin maupun dalam mehalalkan segala cara untuk mencapai suatu tujuan dinilai sudah optimal, hal ini terlihat dari pendapat responden yang menyatakan bahwa petugas Dinas Pendidikan dan Kebudayaan selalu menghindari penyimpangan dalam melaksanakan pekerjaan.

Sikap petugas yang selalu menghindari penyimpangan dalam melaksanakan pekerjaan dan ketepatan waktu dalam menyelesaikan suatu pekerjaan sangat dibutuhkan dalam melaksanakan tugas sehari-hari untuk meningkatkan kinerja yang lebih baik untuk setiap pegawai yang melaksanakan tugas sehingga menghasilkan hasil yang lebih baik.

\section{Inisiatif}

Untuk mengetahui pernyataan dari responden tentang indikator inisiatif, berikut ini penulis sajikan tabel berikut ini :

\section{Pendapat Responden Tentang Inisiatif}

\begin{tabular}{llllllllll} 
No & Indikator & \multicolumn{3}{c}{ Pilihan Responden } & & Jumlah & Indeks & Indek \\
Rata-Rata
\end{tabular}


Dari hasil pekerjaan sesuai dengan target, ternyata responden menyatakan tanggapan setuju bahwa inisiatif pegawai sudah terlaksana dengan baik dengan persentase jawabannya yang paling tinggi adalah setuju, walaupun ada yang berpendapat raga-ragu bahwa inisiatif pegawai dalam melaksanakan tugas sudah baik. Dalam melaksanakan pekerjaan ditargetkan bahwa hasil pekerjaan yang dilaksanakan oleh pegawai sesuai dengan inisiatif dari pegawai, sehingga program kerja yang telah dibuat akan selesai sesuai dengan jadwal yang telah ditentukan. Dominannya pendapat yang menyatakan sudah sesuai target hasil pekerjaan yang diselesaikan, itu disebabkan adanya inisiatif dari pegawai untuk menyelesaikan suatu pekerjaan sehingga pegawai bekerja dengan maksimal.

\section{Kemampuan}

Untuk mengetahui pernyataan dari responden tentang indikator kemampuan, berikut ini penulis sajikan pada tabel berikut ini

Pendapat Responden Tentang Kemampuan

\begin{tabular}{|c|c|c|c|c|c|c|c|c|c|}
\hline \multirow{2}{*}{ No } & \multirow{2}{*}{ Indikator } & \multicolumn{5}{|c|}{ Pilihan Responden } & \multirow{2}{*}{ Jumlah } & \multirow{2}{*}{ Indeks } & \multirow{2}{*}{$\begin{array}{l}\text { Indek } \\
\text { Rata-Rata }\end{array}$} \\
\hline & & 1 & 2 & 3 & 4 & 5 & & & \\
\hline 1 & $\begin{array}{lr}\text { Pengetahuan dan } & \text { kemampuan sesuai } \\
\text { dengan tugasnya } & \end{array}$ & 0 & 0 & 16 & 37 & 1 & 54 & 201 & 3.7 \\
\hline 2 & $\begin{array}{l}\text { Kemampuan } \\
\text { mengendalikan emosi }\end{array}$ & 0 & 4 & 14 & 35 & 1 & 54 & 195 & 3.6 \\
\hline \multicolumn{2}{|c|}{ Jumlah } & & & & & & & & 7.3 \\
\hline \multicolumn{2}{|c|}{ Rata-rata } & & & & & & & & 3.7 \\
\hline
\end{tabular}

Sumber : Data Primer yang diolah, 2017

Berdasarkan tabel di atas, ternyata pendapat responden menilai bahwa para pegawai Dinas Pendidikan dan Kebudayaan Kabupaten Subang selalu menghasilkan pekerjaan dengan sasaran dinilai sudah baik. Hal ini terlihat dari dominannya persentase responden yang sudah setuju terhadap kemampuan para pegawai yang diraharapkan. Tapi ada sebagian dari responden yang menilai ragu-ragu bahwa pegawai Dinas Pendidikan dan Kebudayaan Kabupaten Subang selalu menghasilkan pekerjaan dengan sasaran dinilai sudah baik.

Sudah baiknya penilaian dari responden terkait dengan aspek kemampuan pegawai akan berpengaruh pada kinerja pegawai lain sehingga termotivasi untuk melaksanakan pekerjaan dengan hasil sesuai dengan yang diharapkan. Sehingga program Dinas Pendidikan dan Kebudayaan Kabupaten Subang dapat berjalan sesuai dengan visi dan misi dinas.

\section{Komunikasi}

Untuk mengetahui pernyataan dari responden tentang indikator komunikasi, berikut ini penulis $\mathrm{s}$ ajikan pada tabel berikut ini :

\section{Pendapat Responden Tentang Komunikasi}

\begin{tabular}{llllllllll} 
No & \multicolumn{9}{c}{ Pilihan Responden } \\
& 1 & 2 & 3 & 4 & 5 & Jumlah & Indeks & Indek \\
Rata-Rata
\end{tabular}


Dari aspek memaksimalkan dalam komunikasi pegawai dan atasan, ternyata responden yang memberikan tanggapan setuju persentasenya paling tinggi, tetapi ada juga ada yang memberikan tanggapan ragu-ragu bahwa para pegawai telah memaksimalkan melaksanakan komunikasi dengan pimpinan dalam melaksanakan pekerjaan.

Berdasarkan tabel di atas, tampak bahwa pelaksanaan komunikasi antara bawahan sama atasan yang dilakukan oleh pegawai Dinas Pendidikan dan Kebudayaan Kabupaten Subang dapat diterima oleh pimpinan, itu terlihat dari dominannya jawaban responden yang memberikan jawaban setuju.

\section{Rekapitulasi Skor Variabel Kinerja Pegawai}

Untuk mengetahui hasil rekapitulasi pernyataan dari responden tentang Variabel Kinerja Pegawai, berikut ini penulis sajikan tabel berikut ini :

\section{Pendapat Responden Tentang Variabel Kinerja}

\begin{tabular}{|c|c|c|c|c|c|c|c|c|c|}
\hline \multirow{2}{*}{ No } & \multirow{2}{*}{ Indikator } & \multicolumn{5}{|c|}{ Pilihan Responden } & \multirow{2}{*}{ Jumlah } & \multirow{2}{*}{ Indeks } & \multirow{2}{*}{$\begin{array}{l}\text { Indek } \\
\text { Rata-Rata }\end{array}$} \\
\hline & & 1 & 2 & 3 & 4 & 5 & & & \\
\hline 1 & Cermat & 0 & 2 & 21 & 31 & 0 & 54 & 191 & 3.5 \\
\hline 2 & Terampil & 0 & 0 & 17 & 36 & 1 & 54 & 200 & 3.7 \\
\hline 3 & $\begin{array}{l}\text { Dapat mengatasi setiap } \\
\text { kendala }\end{array}$ & 0 & 3 & 21 & 30 & 0 & 54 & 189 & 3.5 \\
\hline 4 & $\begin{array}{l}\text { Penyelesaian } \\
\text { pekerjaan tepat waktu }\end{array}$ & 0 & 0 & 15 & 36 & 3 & 54 & 204 & 3.8 \\
\hline 5 & $\begin{array}{l}\text { Pegawai datang ke } \\
\text { kantor tepat waktu }\end{array}$ & 0 & 1 & 10 & 39 & 4 & 54 & 208 & 3.9 \\
\hline 6 & $\begin{array}{l}\text { Penyampaian laporan } \\
\text { tepat waktu }\end{array}$ & 0 & 8 & 18 & 28 & 0 & 54 & 182 & 3.4 \\
\hline 7 & $\begin{array}{l}\text { Memutuskan suatu } \\
\text { tindakan dengan tepat }\end{array}$ & 0 & 1 & 15 & 37 & 1 & 54 & 200 & 3.7 \\
\hline 8 & $\begin{array}{l}\text { Mempunyai kemauan } \\
\text { memberikan saran dan } \\
\text { masukan }\end{array}$ & 0 & 2 & 18 & 32 & 2 & 54 & 196 & 3.6 \\
\hline 9 & $\begin{array}{l}\text { Pengetahuan dan } \\
\text { kemampuan sesuai } \\
\text { dengan tugasnya }\end{array}$ & 0 & 0 & 16 & 37 & 1 & 54 & 201 & 3.7 \\
\hline 10 & $\begin{array}{l}\text { Kemampuan } \\
\text { mengendalikan emosi }\end{array}$ & 0 & 4 & 14 & 35 & 1 & 54 & 195 & 3.6 \\
\hline 11 & $\begin{array}{l}\text { Mampu bekerjasama } \\
\text { dengan atasan }\end{array}$ & 0 & 4 & 19 & 28 & 3 & 54 & 192 & 3.6 \\
\hline 12 & $\begin{array}{l}\text { Mampu bekerja sama } \\
\text { dengan teman kerja }\end{array}$ & 0 & 6 & 16 & 32 & 0 & 54 & 188 & 3.5 \\
\hline \multicolumn{2}{|c|}{ Jumlah } & & & & & & & & 43.4 \\
\hline \multicolumn{2}{|c|}{ Rata-rata } & & & & & & & & 3.6 \\
\hline
\end{tabular}

Berdasarkan tabel di atas, ternyata para pegawai Dinas Pendidikan dan Kebudayaan Kabupaten Subang sudah meraih kinerja dengan baik sesuai dengan pengukuran yang diinginkan. Persentase jawaban responden yang menyatakan ragu bahkan tidak setuju dengan raihan kinerja individu ternyata persentasenya tidak terlalu dominan. Sekalipun

demikian, terdapat juga pegawai yang dianggap oleh pimpinan apa yang dilakukan terkait dengan pekerjaannya sudah mencapai tingkat kinerja yang diinginkan. Cukup dominannya pegawai yang sudah mencapai kinerja individu dalam pelaksanaan tugas sehari-hari, tentu akan meningkatkan kualitas kinerja yang rutin dilaksanakan setiap hari kerja oleh pegawai. 
Pengaruh Pemberian Insentif Terhadap Kinerja Pegawai Pada Dinas Pendidikan dan Kebudayaan Kabupaten Subang

\section{Analisis Korelasi}

Untuk melihat ada atau tidak adanya pengaruh pemberian insentif terhadap kinerja pegawai pada Dinas Pendidikan dan Kebudayaan Kabupaten Subang dengan menggunakan Korelasi. Nilai Korelasi Paraial menggunakan Statistic Programme For Social Science (SPSS), dengan perolehan data sebagai berikut :

\section{Correlations}

Hasil Pengujian Koefisien Korelasi ( $r$ )

\begin{tabular}{|ll|l|l|}
\hline & & Kinerja & $\begin{array}{l}\text { Pemberian_Ins } \\
\text { entif }\end{array}$ \\
\hline Pearson Correlation & Kinerja & 1.000 & .810 \\
& Pemberian_Insentif & .810 & 1.000 \\
\hline Sig. (1-tailed) & Kinerja &. & .000 \\
& Pemberian_Insentif & .000 &. \\
\hline $\mathrm{N}$ & Kinerja & 54 & 54 \\
& Pemberian_Insentif & 54 & 54 \\
\hline
\end{tabular}

Hasil dari data tersebut dapat diketahui bahwa besarnya hubungan pemberian insentif terhadap kinerja pegawai pada Dinas Pendidikan dan Kebudayaan Kabupaten Subang adalah 0,810 , dengan bantuan tabel koefisien korelasi seperti yang dikemukakan oleh Sugiyono (2010 : 149) nilai tersebut berada pada interval koefisien $0,800-1,000$ dan termasuk dalam kategori "Sangat Kuat".
Analisis regresi digunakan untuk melihat besarnya pengaruh pemberian insentif terhadap kinerja pegawai pada Dinas Pendidikan dan Kebudayaan Kabupaten Subang. Dengan demikian dapat diketahui persamaan regresi untuk pengaruh pemberian insentif terhadap kinerja pada Dinas Pendidikan dan Kebudayaan Kabupaten Subang Subang adalah sebagai berikut:

\section{Analisis Regresi}

\section{Coefficients $^{\mathrm{a}}$}

\section{Hasil Pengujian Regresi Linier Sederhana}

\begin{tabular}{|c|c|c|c|c|c|c|}
\hline \multirow{2}{*}{\multicolumn{2}{|c|}{ Model }} & \multicolumn{2}{|c|}{$\begin{array}{l}\text { Unstandardized } \\
\text { Coefficients }\end{array}$} & \multirow{2}{*}{\begin{tabular}{|l} 
Standardized \\
Coefficients
\end{tabular}} & \multirow[b]{2}{*}{$\mathrm{t}$} & \multirow[b]{2}{*}{ Sig. } \\
\hline & & B & Std. Error & & & \\
\hline \multirow[t]{2}{*}{1} & (Constant) & 9.668 & 3.408 & & 2.837 & .006 \\
\hline & Pemberian_Insentif & .625 & .063 & .810 & 9.960 & .000 \\
\hline
\end{tabular}

a. Dependent Variable: Kinerja

$$
Y=a+b X
$$

Berdasarkan tabel di atas diketahui:

$\mathrm{Y}=$ Subyek dalam variabel dependen yang diprediksikan (Variabel Kinerja) $\mathrm{a}=$ Harga $\mathrm{Y}$ ketika harga $\mathrm{X}=0$ (harga konstan $)=(9.668)$

$\mathrm{b}=$ Angka arah atau koefisien regresi, yang menunjukkan angka peningkatan ataupun penurunan 
variabel dependen yang didasarkan pada perubahan variabel independen. Bila (+) arah garis naik, dan bila (-) arah garis turun $=(0.625)$

$\mathrm{X}=$ Subyek pada variabel independen yang mempunyai nilai tertentu, (variabel Pemberian insentif)

$\mathrm{Y}=9.668+[0.625 .(\mathrm{X})]$

Asumsi :

$\mathrm{Y}=9.668+[0.625 .5]$

$\mathrm{Y}=9.668+3.125$

$\mathrm{Y}=12.793$

Bila diasumsikan harga $X$ disubtitusikan 5 (lima) poin, maka berpengaruh pada naiknya harga Y menjadi 12.793 , jadi perkiraan nilai rata-rata pemberian insentif sebesar 12.793. Dari persamaan regresi di atas dapat diartikan bahwa, bila nilai rata-rata kinerja bertambah 1 (satu), maka rata-rata pemberian insentif bertambah 0.625 , atau bila rata-rata kinerja bertambah 5 (lima) maka pemberian insentif akan bertambah sebesar 3.125 , sehingga dapat disimpulkan bahwa kinerja pegawai berpengaruh positif dan signifikan terhadap pemberian insentif pada Dinas Pendidikan dan Kebudayaan Kabupaten Subang

\section{Koefisien Determinasi ( $\mathbf{r}^{2}$ )}

Koefisien determinasi digunakan untuk mencari pengaruh varians variabel dengan mengkuadratkan koefisien korelasi yang telah ditemukan dan selanjutnya dikalikan dengan 100\% (Sugiyono, $2010: 154$ ).

Hasil Pengujian Koefisien Determinasi $\left(\mathrm{r}^{2}\right)$
\begin{tabular}{|l|l|l|l|l|}
\hline Model Summary & \\
\hline Model & $\mathrm{R}$ & R Square & $\begin{array}{l}\text { Adjusted } \\
\text { Square }\end{array}$ & $\begin{array}{l}\text { Std. Error of } \\
\text { the Estimate }\end{array}$ \\
\hline 1 & $.810^{\mathrm{a}}$ & .656 & .649 & 2.50841 \\
\hline
\end{tabular}

\section{a. Predictors: (Constant), Pemberian_Insentif}

b. Dependent Variable: Kinerja

Besarnya pengaruh variabel pemberian insentif terhadap kinerja di Dinas Pendidikan dan Kebudayaan Kabupaten Subang sebesar $65,6 \%$. Sebaran sisanya sebesar $34,4 \%$ dipengaruhi oleh variabel lain yang tidak diteliti disini pengawasan, motivasi, sosialisasi dan sebagainya.

\section{Taraf Signifikasi ( F )}

Taraf signifikasi atau signification level adalah kesediaan dan keberanian peneliti untuk secara maksimal mengambil resiko kesalahan dalam menguji hipotesis (Burhan, 2013 : 65). Nilai signifikansi dari hipotesis adalah nilai kebenaran dari hipotesis yang diterima atau ditolak. Secara umum digunakan angka signifikansi sebesar 0,01 dan 0,05 dengan ketentuan jika nilai sig. $<0,05$ maka model regresi adalah linier.

Signifikansi adalah kemampuan untuk digenelasisasikan dengan kesalahan tertentu. Ada hubungan signifikan berarti hubungan itu dapat digeneralisasikan. Ada perbedaan signifikan berarti perbedaaan itu dapat digeneralisasikan.

Tabel 4.20

Uji Signifikasi ( F )

ANOVA $^{\mathrm{b}}$

\begin{tabular}{|c|c|c|c|c|c|c|}
\hline \multicolumn{2}{|c|}{ Model } & Sum of Squares & $\mathrm{df}$ & Mean Square & $\mathrm{F}$ & Sig. \\
\hline \multirow[t]{3}{*}{1} & Regression & 624.144 & 1 & 624.144 & 99.195 & $.000^{\mathrm{a}}$ \\
\hline & Residual & 327.190 & 52 & 6.292 & & \\
\hline & Total & 951.333 & 53 & & & \\
\hline
\end{tabular}

a. Predictors: (Constant), Pemberian_Insentif

b. Dependent Variable: Kinerja

Berdasarkan tabel 4.19 diperoleh nilai Sig. $=0.000$ yang berarti $<$ kriteria signifikan
$(0,05)$, dengan demikian model persamaan regesi berdasarkan data penelitian adalah 
signifikan, artinya model regresi liner memenuhi kriteria linieritas.

Permasalahan yang ingin dijawab dalam penelitian ini adalah: (1) Bagaimana pelaksanaan pemberian insentif pada Dinas Pendidikan dan Kebudayaan Kabupaten Subang, (2) Bagaimana kinerja pegawai pada Dinas Pendidikan dan Kebudayaan Kabupaten Subang, (3) Apakah terdapat pengaruh pemberian insentif terhadap kinerja pegawai pada Dinas Pendidikan dan Kebudayaan Kabupaten Subang.

Berdasarkan hasil pengujian yang telah diuraikan, maka terbukti bahwa pemberian insentif berpengaruh secara positif dan signifikan terhadap kinerja pegawai. Uraian selengkapnya akan dijelaskan sebagai berikut:

\section{Pemberian Insentif}

Salah satu faktor penentu keberhasilan organisasi adalah sumber daya manusia sebagai tenaga kerja ataupun sebagai pegawai didalam organisasi. Keberhasilan tersebut sangat ditentukan seberapa jauh pegawai tersebut merasa memiliki organisasi yang pada akhirnya akan menimbulkan loyalitas kepada organisasi, Sehubungan dengan hal tersebut, pimpinan organisasi didalam mengelola organisasi harus menempatkan pegawai tidak hanya sebagai faktor produksi tetapi harus ditempatkan sebagai partner dan berupaya untuk meningkatkan kesejahteraan pegawai melalui pemberian bonus, gaji yang layak maupun Insentif untuk mencapai tujuan organisasi melalui peningkatan kinerja pegawai.

Menurut Hasibuan (2001 : 117), mengemukakan bahwa: "Insentif adalah tambahan balas jasa yang diberikan kepada pegawai tertentu yang prestasinya di atas prestasi standar. Insentif ini merupakan alat yang dipergunakan pendukung prinsip adil dalam pemberian kompensasi". Sedangkan menurut Mangkunegara (2002:89), mengemukakan bahwa: "Insentif adalah suatu bentuk motivasi yang dinyatakan dalam bentuk uang atas dasar kinerja yang tinggi dan juga merupakan rasa pengakuan dari pihak organisasi terhadap kinerja pegawai dan kontribusi terhadap organisasi (organisasi)."

Insentif sebagai sarana motivasi yang mendorong para pegawai untuk bekerja dengan kemampuan yang optimal, yang dimaksudkan sebagai pendapatan ekstra di luar gaji atau upah yang telah ditentukan. Pemberian insentif dimaksudkan agar dapat memenuhi kebutuhan para pegawai dan keluarga mereka. Istilah sistem insentif pada umumnya digunakan untuk menggambarkan rencana-rencana pembayaran upah yang dikaitkan secara langsung atau tidak langsung dengan berbagai standar kinerja pegawai atau profitabilitas organisasi.

Memperhatikan hasil penelitian diatas, maka cukup gambaran bahwa pemberian insentif yang terarah terhadap pegawai masih perlu dikaji kembali. Pemberian insentrif yang terarah akan sangat efektif untuk mendorong kinerja pegawai lebih baik, karena selain dapat menambah penghasilan para pegawainya, pemberian insentif yang terarah dapat menumbuhkan atau meningkatkan rasa bangga dan kesenangan yang tinggi terhadap organisasi dan hal ini dapat dilihat dari moral kerja yang tinggi dari para pegawainya seperti tingkat kinerja yang baik, kerjasama dan tanggung jawab yang tinggi terhadap organisassi.

Namun apabila pemberian insentif yang terarah tersebut tidak dapat dilakukan, dampak yang akan ditimbulkan adalah semangat kerja yang rendah dari para pegawainya seperti yang sudah dijelaskan di atas. Dan apabila masalah ini dibiarkan berlarut-larut, tidak menutup kemungkinan dampak yang akan ditimbulkan oleh para pegawai terhadap organisasi akan jauh lebih negatif dari apa yang diperkirakan, karena bagaimanapun para pegawai-lah yang pada akhirnya menentukan keberhasilan atau kegagalan suatu kebijakan, strategi, maupun langkah-langkah kegiatan operasional oleh pimpinan organisasi yang siap dilaksanakan.

Dari hasil penelitian pada Dinas Pendidikan dan Kebudayaan Kabupaten Subang diperoleh hasil bahwa sebagian besar responden telah memperoleh insentif secara memadai. Sekalipun demikian, terdapat juga sebagian pegawai yang belum memperoleh insentif secara memadai dengan persentase cukup signifikan. Dominannya persentase pegawai yang sudah merasakan dampak dari insentif dimungkinkan oleh tanggapan responden yang sudah berstatus PNS, terlebih lagi bagi mereka yang sudah memperoleh tunjangan karena jabatannya, baik struktural maupun fungsional.

\section{Kinerja Pegawai}


Pegawai memiliki peranan yang sangat penting dalam menyelenggarakan kegiatan dalam sebuah organisasi, hal ini disebabkan karena pegawai merupakan salah satu unsur pendukung yang secara langsung melaksanakan kegiatan organisasi dalam upayanya untuk mencapai tujuan yang telah ditetapkan oleh organisasi. Tangkilisan (2002 : 25) menyatakan bahwa unsur manusia merupakan unsur penting, karena manusia selalu berperan aktif dan dominan dalam setiap organisasi. Manusia merupakan perencana, pelaku sekaligus penentu terwujudnya tujuan organisasi. Dengan demikian pegawai dalam sebuah organisasi dituntut untuk memiliki kemampuan dalam menjalankan tugas dan tanggungjawabnya untuk berpartisipasi dalam kegiatan organisasi sehingga menghasilkan kinerja yang optimal.

Kinerja merupakan perbandingan hasil kerja yang dicapai oleh pegawai dengan standar yang telah ditentukan. Kinerja juga dapat diartikan sebagai hasil yang dicapai oleh pegawai dengan standar yang ditentukan. Kinerja juga memiliki arti hasil yang dicapai oleh seseorang baik kuantitas maupun kualitas sesuai dengan tanggung jawab yang diberikan kepadanya. Kinerja seseorang dapat dipengaruhi oleh tingkat pendidikan, inisiatif, pengalaman kerja dan motivasi pegawai. Hasil kerja seseorang akan memberikan umpan balik bagi orang itu sendiri untuk selalu aktif melakukan kerjanya secara baik dan diharapkan akan menghasilkan mutu pekerjaan yang baik (Masrukhin dan Waridin, 2006).

Berdasarkan hasil analisis data di atas, pegawai yang dianggap oleh pimpinan sudah melaksanakan pekerjaan dengan tingkat kinerja yang diinginkan. Cukup dominannya pegawai yang sudah mencapai kinerja individu dalam pelaksanaan tugas sehari-hari, tentu akan meningkatkan kualitas kinerja yang rutin dilaksanakan setiap hari kerja oleh pegawai Dinas Pendidikan dan Kebudayaan Kabupaten Subang.

\section{Pengaruh Insentif Terhadap Kinerja Pegawai}

Insentif dengan kinerja pegawai saling berhubungan. Insentif merupakan suatu dorongan pada seseorang agar mau bekerja dengan baik dan agar lebih cepat mencapai tingkat kinerja yang lebih tinggi sehingga dapat membangkitkan gairah kerja dan motivasi seorang pegawai. jadi seseorang mau bekerja dengan baik apabila dalam dirinya terdapat motivasi, yang menjadi masalah adalah bagaimana pula menciptakan gairah kerja dan motivasinya, sebab walaupun motivasi sudah terbentuk apabila tidak disertai dengan gairah kerjanya maka tetap saja pegawai tersebut tidak akan bisa bekerja sesuai yang diharapkan.

Sedangkan kinerja pegawai mempunyai hubungan erat dengan masalah produktivitas karena merupakan indikator dalam menentukan bagaimana usaha untuk mencapai tingkat produktivitas yang tinggi dalam suatu organisasi/instansi. Sehubungan dengan hal tersebut maka upaya untuk mengadakan penilaian terhadap kinerja di suatu organisasi merupakan hal yang sangat penting. Dalam memotivasi dan mendorong peningkatan kinerja pegawai maka suatu organisasi memberlakukan sebuah sistem insentif individu untuk setiap pencapaian produksi. Meskipun bagian persentase insentif individu ini tetap, namun besarnya nilai nominal yang diterima pegawai bisa berbeda antar pegawai yang satu dengan pegawai yang lainnya, bergantung pada pencapaian kinerja yang dibebankan kepadanya. Oleh karena itu, perlu diketahui penilaian pegawai terhadap pemberian insentif individu yang diterapkan oleh organisasi. Hasil pembahasan menunjukkan bahwa insentif individu dipandang dari sisi pegawai adalah tinggi.

Dengan tingginya insentif individu ini, maka persepsi pegawai terhadap pemberian insentif individu dari organisasi adalah cukup baik. Dan jika dilihat dari sudut pandang organisasi, tingginya insentif ini akan mempengaruhi pemikiran organisasi. Sedangkan penilaian kinerja jika dilihat dari sudut pandang organisasi adalah tinggi, dan dengan tingginya kinerja pegawai, maka organisasi akan mampu untuk meningkatkan outputnya. Berdasarkan pada penelitian ini, maka dapat disimpulkan bahwa insentif individu mempengaruhi tingkat kinerja pegawai dalam suatu organisasi.

Sistem insentif dengan cara ini langsung mengkaitkan besarnya insentif dengan kinerja yang telah ditunjukkan oleh pegawai yang bersangkutan. Berarti besarnya insentif tergantung pada banyak sedikitnya hasil yang dicapai dalam waktu kerja pegawai. Cara ini dapat diterapkan apabila hasil kerja diukur secara kuantitatif, memang dapat 
dikatakan bahwa dengan cara ini dapat mendorong pegawai yang kurang produktif menjadi lebih produktif dalam bekerjanya. Di samping itu juga sangat menguntungkan bagi pegawai yang dapat bekerja cepat dan berkemampuan tinggi. Sebaliknya sangat tidak baik bagi pegawai yang bekerja lamban atau pegawai yang sudah berusia agak lanjut.

Sistem pemberian insentif dan penghargaan tersebut diberikan kepada pegawai yang berprestasi berupa penghargaan materi maunpun non materi, sedangkan pegawai yang tidak berprestasi mendapatkan disinsentif berbentuk teguran, peringatan, penurunan pangkat. Pegawai yang berprestasi perlu memperoleh penghargaan yang pada gilirannya dapat memacu semangat dan prestasi kerja yang lebih baik lagi. Insentif dapat dikembangkan dengan memperhatikan beberapa faktor, antara lain gaji yang memadai, jaminan fasilitas penunjang dan kondisi kerja, hadiah berupa penghargaan serta jaminan hari tua. Faktor-faktor tersebut harus dikembangkan dalam proses penyelenggaraan organisasi kedepan sehingga mampu menumbuhkan motivasi dari dalam diri setiap pegawai dengan maksud mampu berkreatifitas dan memiliki inovasi-inovasi terbaru dalam pengembangan organisasi.

Hasil analisis data penelitian pemberian insentif dan kinerja pegawai, dari analisis koefisien pengaruh diperoleh hasil bahwa hubungan kedua variabel tersebut termasuk dalam kategori erat. Hal ini menjelaskan bahwa setiap perubahan variabel pemberian insentif akan memberikan kontribusi yang positif terhadap perubahan kinerja pegawai.

Dari hasil pengolahan data dapat diketahui bahwa besarnya hubungan pemberian insentif terhadap kinerja pegawai pada Dinas Pendidikan dan Kebudayaan Kabupaten Subang adalah 0,810 , dengan bantuan tabel koefisien korelasi seperti yang dikemukakan oleh Sugiyono (2010 : 149) nilai tersebut berada pada interval koefisien $0,800-1,000$ dan termasuk dalam kategori "Sangat Kuat".

Sedangkan besarnya pengaruh variabel pemberian insentif terhadap kinerja pegawai di Dinas Pendidikan dan Kebudayaan Kabupaten Subang sebesar $65,6 \%$. Sebaran sisanya sebesar $34,4 \%$ dipengaruhi oleh variabel lain yang tidak diteliti disini pengawasan, motivasi, sosialisasi dan sebagainya.
Jadi hipotesis yang diajukan dalam penelitian ini teruji secara empirik yaitu "Terdapat pengaruh pemberian insentif terhadap kinerja pegawai Dinas Pendidikan dan Kebudayaan Kabupaten Subang" dapat diterima.

\section{SIMPULAN}

Setelah penulis mengadakan penelitian tentang pengaruh pemberian insentif terhadap kinerja pegawai pada Dinas Pendidikan Dan Kebudayaan Kabupaten Subang, baik dengan pengamatan langsung maupun tidak langsung, membandingkan teori dengan kenyataan yang ada dilapangan, serta didukung oleh hasil kuesioner berdasarkan perhitungannya, maka penulis menarik kesimpulan sebagai berikut :

1. Dalam variabel pemberian insentif dengan delapan belas indikator, frekwensi jawaban responden ternyata didominasi oleh pendapat yang menyetujui bahwa pemberian insentif bagi pegawai Dinas Pendidikan Dan Kebudayaan, baik finansial maupun non-finansial sudah memenuhi harapan yang diinginkan. Sekalipun demikian, terdapat juga pegawai yang belum terpenuhi harapannya akan insentif finansial maupun non-finansial. Dimungkinkan, aspek insentif ini berkaitan dengan status kepegawaian yang dimiliki olehpara pegawai, dimana mereka yang berstatus PNS yang memiliki jabatan struktural akan memperoleh besaran insentif yang relatif lebih tinggi.

2. Dalam variabel Kinerja Pegawai di Dinas Pendidikan Dan Kebudayaan Kabupaten Subang yang terbagi ke dalam sebelas indikator dan hasilnya didominasi oleh pendapat responden yang menyetujui, dengan demikian dapat disimpulkan bahwa Kinerja Pegawai di Dinas Pendidikan Dan Kebudayaan Kabupaten Subang sudah tercapai dengan baik

3. Dari hasil pengolahan data dapat diketahui bahwa besarnya hubungan pemberian insentif terhadap kinerja pegawai pada Dinas Pendidikan dan Kebudayaan Kabupaten Subang adalah 0,810 nilai tersebut berada pada interval koefisien 0,800 - 1,000 dan termasuk dalam kategori "Sangat Kuat". Sedangkan besarnya pengaruh variabel pemberian 
insentif terhadap kinerja pegawai di Dinas Pendidikan dan Kebudayaan Kabupaten Subang sebesar $65,6 \%$. Sebaran sisanya sebesar $34,4 \%$ dipengaruhi oleh variabel lain yang tidak diteliti disini pengawasan, motivasi, sosialisasi dan sebagainya.

\section{DAFTAR PUSTAKA}

Arikunto, Suharsimi. 2003. Prosedur Penelitian suatu Pendekatan Praktek. Jakarta : Rineka Cipta.

Dessler Gary, 2001, Manajemen Prestasi Kerja, Terjemahan Agus Dharma, Jakarta : Rajawali Pers

Effendi Marihot Tua, 2002. Manajemen Sumber Daya Manusia. Jakarta: Grasindo.

Foster, Bill dan Karen R. Seeker, 2001. Pembinaan Untuk Meningkatkan Kinerja Karyawan. Jakarta: Penerbit PPM.

Handoko, T. Hani. 2002. Manajemen. Yogyakarta : BPFE.

Hasibuan, Malayu P.S, 2001, Manajemen Sumber Daya Manusia, PT. Bumi Aksara : Jakarta.

Husnan Suad. 2002. Dasar-dasar Manajemen Keuangan. Yogyakarta : UPP AMP YKPN

Indiahono Dwiyanto, 2009, Perbandingan Administrasi Publik, Yogyakarta : Gava Media.

Kartono Kartini. 2005, Pemimpin dan Kepemimpinan. Jakarta: Raja Grafindo Persada
Manullang, 2006, Dasar-Dasar Manajemen, Jakarta : Ghalia Indonesia

Nawawi, Handari, 2003, Metode Penelitian Sosial, Yogyakarta : Gadjah Mada University Press

Pangabean S. Mutiara, 2002, Manajemen Sumber Daya Manusia, Yogyakarta : Ghalia Indonesia.

Panggabean, S., Mutiara. 2004. Manajemen Sumber Daya Manusia. Bogor: Ghalia Indonesia

Ranupandojo, H., dan Suad Husnan, 2002, Manajemen Personalia, Yogyakarta: BPFE.

Rivai Veithzal, 2003, Evaluasi Proyek, Bandung : Pionir

Sarwoto, 2001, Dasar-dasar Organisasi dan Manajemen, Jakarta : Ghalia Indonesia.

Sedarmayanti, 2001, Tata Kerja dan Produktivitas Kerja, Jakarta : Mandar Maju.

Siagian P, Sondang. 2002. Filsafat Administrasi, Jakarta : Gunung Agung

Sugiyono, 2010, Motode Penelitian Administrasi, Bandung : Alfabeta.

Sulistiyani, Teguh Ambar dan Rosidah, 2003, Manajemen Sumber Daya Manusia, Yogyakarta : Ghalia Ilmu.

Tangkilisan, Hesel Nogi. 2002. Kebijakan Publik Yang Membumi. Yogyakarta: Lukman Offset YPAPI.

Wibowo. 2012. Manajemen Kinerja. PT. Raja Grafindo Parsada: Jakarta. 